
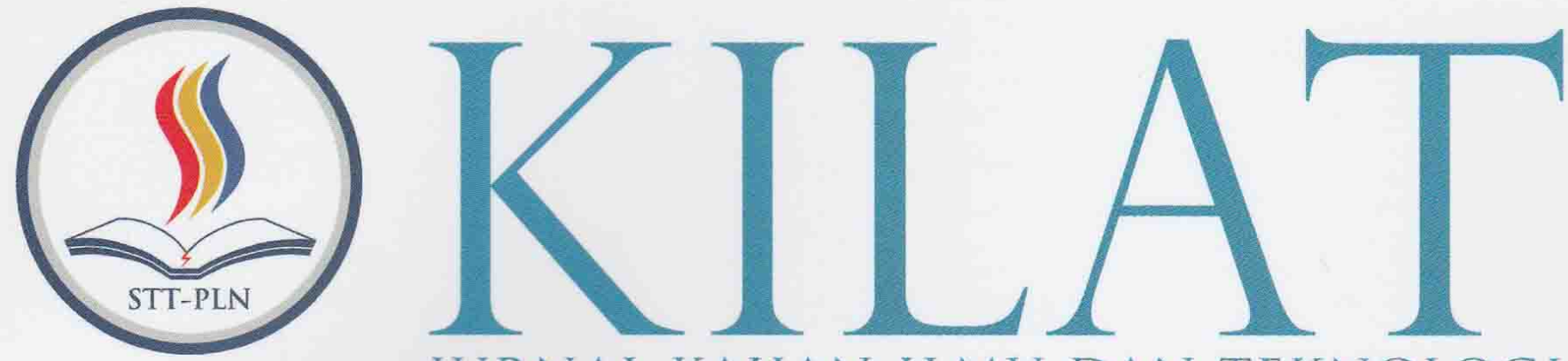

JURNAL KAJIAN ILMU DAN TEKNOLOGI

Endah Lestari: Irma Wirantina K: Ranti Hidayawanti

Faisal:

Muhammad Ridwan: Mardawati

Gita Puspa Artiani: Indah Handayasari

Kresna Ramanda; Irmawati Carolina

Ratna Mutu Manikam:

Farid Setiawan

Rayung Wulan

Roni Kartika Pramuyanti

Rr. Mekar Ageng Kinasti; Djoko Nugroho Notodisuryo

Satria;

Ayu Setiawati Agustini

Syam Gunawan: Pritasari Palupiningsih

Ali Ridho Gumelar: Anton: Ummu Radiyah

M. Yoga Distra Sudirman: Yessy Fitriani
ANALISA TAMAN ATAP DALAM UPAYA MENGURANGI LIMPASAN AIR HUJAN PADA BANGUNAN PERKOTAAN

OPTIMASI DIAGRAM LAYANAN PEMBELIAN DALAM MENDUKUNG MANAJEMEN HUBUNGAN PELANGGAN

OPTIMALISASI PENGOLAHAN SAMPAH ORGANIK DENGAN TEKNOLOGI BIODIGESTER SEBAGAI UPAYA KONSERVASI LINGKUNGAN

SELEKSI FITUR ALGORITMA NEURAL NETWORK MENGGUNAKAN PARTICLE SWARM OPTIMIZATION UNTUK MEMPREDIKSI KELAHIRAN PREMATUR

RANCANG BANGUN MEDIA BELAJAR FISIKA DASAR UNTUK MAHASISWA BERBASIS ANDROID

ANALISIS GLOBAL POSITIONING INFRASTRUKTUR DAN JARINGAN SOSIAL MEDIA DALAM BISNIS APLIKASI TRANSPORTASI DARAT ONLINE DI JAKARTA

PENGARUH INOVASI ANTENA PADA SIARAN TELEVISI MOBIL

PEMANFAATAN LIMBAH PEMBAKARAN BATUBARA (BOTTOM ASH) PADA PLTU SURALAYA SEBAGAI MEDIA TANAM DALAM UPAYA MENGURANGI PENCEMARAN LINGKUNGAN

PENERAPAN METODE GRAPHIC RATING SCALE (GRS) DALAM PENILAIAN KINERJA KARYAWAN

PEMBENTUKAN MODEL KLASIFIKASI DATA LAMA STUDI MAHASISWA STMIK INDONESIA MENGGUNAKAN DECISION TREE DENGAN ALGORITMA NBTREE

IMPLEMENTASI LOAD BALANCING DENGAN ALGORITMA EQUAL COST MULTI PATH (ECMP)

RANCANGAN SISTEM PENILAIAN HASIL KINERJA MULTI COMPANY DAN CROSS BUSINESS SECTOR 


\title{
OPTIMALISASI PENGOLAHAN SAMPAH ORGANIK DENGAN TEKNOLOGI BIODIGESTER SEBAGAI UPAYA KONSERVASI LINGKUNGAN
}

\author{
Gita Puspa Artiani ${ }^{1}$; Indah Handayasari ${ }^{2}$ \\ Jurusan Teknik Sipil, Sekolah Tinggi Teknik PLN Jakarta \\ gitapuspa@sttpln.ac.id.
}

\begin{abstract}
ABSTRAK
Sampah merupakan salah satu masalah penting dalam kehidupan masyarakat, khususnya di Indonesia. Volume timbulan sampah semakin meningkat seiring bertambahnya konsumsi masyarakat setiap harinya, yang berdampak kepada penumpukan sampah khususnya di TPST GEMPEL - BEHI. Penumpukan sampah tersebut mengganggu aktivitas masyarakat disekitar TPST. Oleh karena itu diperlukan suatu alternatif pengolahan sampah untuk mengurangi volume sampah yang akan diangkut ke TPA dengan mengolah sampah organik melalui teknologi biodigester. Kondisi ini mendorong peneliti untuk mendesain biodigester tipe fixed dome untuk mengoptimalkan pengolahan sampah. Dari hasil analisa didapatkan volume total reaktor yang digunakan adalah $196,8 \mathrm{~m}^{3}$ untuk mengolah sampah $32,8 \mathrm{~m}^{3} /$ hari. Pemanfaatan teknologi biodigester dapat menambah pendapatan TPST dari penjualan nilai ekonomis sampah sebesar Rp. 58.795.750,-/bulan dan biaya pengeluaran sebesar Rp. 52.320.000,-/bulan dengan PBP (Pay Back Period) 6 bulan. Sehingga dengan desain biodigester terjadi suatu upaya konservasi lingkungan sebagai salah satu langkah untuk meningkatkan kesejahteraan manusia dan mewujudkan kelestarian sumber daya alam.
\end{abstract}

Kata kunci : Sampah, Pengolahan Sampah, Biodigester.

\section{ABSTRACT}

Garbage is one of important issues in the life community, particularly in Indonesia. The volume of garbage heap is increasing along with the increase of public consumption every day, which affects garbage accumulation especially in GEMPEL - BEHI TPST. Therefore, an alternative waste treatment is needed to reduce the volume of waste to be transported to the landfill by utilizing organic waste with anaerobic-digester technology. This condition encourages researchers to design biodigester type fixed dome to optimize waste processing. Based on the research that has been done, Designed anaerobic-digester that had been made can be known the total volume of reactor used is $196,8 \mathrm{~m}^{3}$ to process waste $32,8 \mathrm{~m}^{3} /$ day. From utilization the anaerobic-digester technology, it provides benefits for the community such as income from the sale of economic value of waste are Rp. 58.795.750,- per month and value of expenses are Rp 52.320.000,- per month with pay back period are 6 month. So with the design, it occurs environmental conservation efforts as one step to improve human welfare and realize the sustainability of natural resources.

Keywords : Gerbage, Garbage Processing, Anaerobic-Digester.

\section{PENDAHULUAN}

Sampah merupakan salah satu masalah penting dalam kehidupan masyarakat, khususnya di Indonesia. Peningkatan volume timbulan sampah dipengaruhi oleh beberapa faktor seperti pertumbuhan penduduk, laju pembangunan, tingkat sosial-ekonomi dan aktivitas masyarakat. Pola pikir masyarakat dengan berpedoman sistem kumpulangkut-buang dengan mengandalkan TPA membuat pengolahan sampah menjadi tidak optimal. Tentunya pandangan seperti ini sangat disayangkan karena tidak akan mampu mengurangi jumlah volume penumpukan sampah yang diproduksi oleh masyarakat.

Seperti halnya TPA Rawa Kucing yang terletak di Kecamatan Neglasari, Kota Tangerang ini mampu menampung sampah sebanyak \pm 1200 ton/hari dari seluruh kelurahan di Tangerang (Sumber: Dinas Kebersihan dan Pertamanan Kota Tangerang). Sampah ini terdiri dari sampah organik, anorganik, residu, dan bahan berbahaya beracun
(B3). Mengingat kebutuhan pupuk di wilayah Tangerang terus meningkat, maka pengelola TPA mengolah sampah untuk dijadikan kompos. Hal ini sangat efektif dilakukan untuk mengatasi penumpukkan sampah yang terjadi. Akan tetapi karena terlalu banyaknya penumpukan sampah dan belum terolah maka diperkirakan 10 tahun kedepan TPA Rawa Kucing tidak dapat menerima sampah kembali (Sumber : bantenterkini.com).

Salah satu penyumbang sampah di TPA Rawa Kucing adalah Tempat Pengolahan Sampah Terpadu (TPST) GEMPEL BEHI yang terletak di kelurahan Petir. TPST ini dikelola oleh organisasi masyarakat Gerakan Masyarakat Peduli Lingkungan Bersih dan Hijau (GEMPEL-BEHI). TPST GEMPEL-BEHI ini masih menggunakan sistem konvensional yaitu dengan mengangkut melalui gerobak mulai pukul 16.00 WIB sampai dengan pukul 24.00 WIB oleh 40 orang penarik gerobak. Volume sampah yang dihasilkan oleh TPST ini sebanyak $87,5 \mathrm{~m}^{3} /$ hari (Sumber : Data Pengelola TPST GEMPEL BEHI). TPST ini 
menampung sampah dari satu kelurahan yang memiliki 26.976 jiwa yang terdiri 6.851 kepala keluarga (Sumber : Data Penduduk Kelurahan Petir tahun 2017).

Letak TPST GEMPEL-BEHI ini berseberangan dengan pasar tradisional dan bersampingan den

gan jalan umum sehingga sampah pasar merupakan penyumbang sampah terbesar dan timbulan sampah yang ada mengganggu jalannya lalu lintas. Komposisi sampah pasar lebih dominan sampah organik, sehingga mendorong pengelola TPST untuk melakukan upaya konservasi lingkungan dengan menjadikan sampah organik menjadi cacahan organik. Selain dijadikan cacahan organik, pengelola juga melakukan pemisahan sampah anorganik yaitu plastik yang dapat dijual kembali, sehingga dengan ini dapat mengurangi jumlah sampah yang dikirim ke TPA Rawa Kucing.

Selama pengoperasian TPST, telah dilaksanakan penelitian untuk mengoptimalkan pengolahan sampah dengan menambahkan alat belt conveyor. Akan tetapi sistem perencanaan yang telah dibuat masih menghasilkan residu sampah ke TPA yaitu sebesar $35 \mathrm{~m}^{3}$ dan masih kurang optimalnya penggunaan alat conveyor dikarenakan waktu tunggu yang terlalu lama sehingga banyak tenaga kerja yang menganggur. Dengan bertambahnya produksi sampah organik dari masyarakat membuat sistem yang direncanakan harus dilakukan pengembangan lebih lanjut untuk mengoptimalkan pengolahan sampah. Maka alternatif pengolahan sampah yang dapat diterapkan untuk menyelesaikan masalah tersebut adalah memanfaatkan sampah organik dengan teknologi biodigester. Teknologi Biodigester nantinya akan menghasilkan keluaran yang bermanfaat seperti listrik, pupuk dan gas metan. Selain itu teknologi biodigester ini lebih ekonomis dan mudah dalam pelaksanaannya sehingga dapat dijadikan suatu upaya konservasi lingkungan. Dengan adanya alternatif tersebut dapat diperoleh desain biodigester yang disesuaikan dengan volume sampah dan alur perencanaan yang telah ada sebelumnya. Sehingga mampu mengurangi volume timbulan sampah dan diharapkan tidak ada sampah yang akan dikirim ke TPA mengingat kondisi TPA tidak dapat menampung sampah lagi dalam jangka waktu tertentu.

\section{a) Pengertian Sampah}

Secara umum, sampah adalah bahan buangan atau sisa yang sudah tidak dipergunakan lagi dan akan menimbulkan gangguan terhadap kesehatan masyarakat (Wikipedia).

Sampah adalah sisa kegiatan sehari-hari manusia atau proses alam yang berbentuk padat. Sampah spesifik merupakan sampah yang karena sifat, konsentrasi atau volumenya memerlukan pengelolaan khusus (UU No.18 Tahun 2008 Tentang Pengelolaan Sampah).

Sampah adalah barang atau benda bekas yang tidak dapat dipakai lagi atau berkurang fungsinya yang harus dibuang, diolah, dan dimusnahkan (Peraturan Daerah Kota Bogor Nomor 5 Tahun 2008 Tentang Retribusi Pelayanan Persampahan).
Sampah adalah limbah yang bersifat padat terdiri dari bahan organik dan bahan anorganik yang dianggap tidak berguna lagi dan harus dikelola agar tidak membahayakan lingkungan dan melindungi investasi pembangunan (SNI 19-4542002 Tentang Tata Cara Teknik Operasional Pengelolaan Sampah Perkotaan).

\section{b) Teknologi Biodigester}

Menurut Muhammad Rizki Syabani (2014), Biodigester sering disebut bangunan biogas yaitu sebuah tangki tertutup tempat bahan organik difermentasi, sehingga menghasilkan gas bio sebagai energi disertai dengan bahan penyubur dari limbah organik.

Proses pembuatan biogas dengan menggunakan biodigester pada prinsipnya adalah menciptakan suatu sistem kedap udara dengan bagian-bagian pokok yang terdiri dari tangki pencerna (digester tank), saluran input bahan baku, saluran output lumpur sisa hasil pencernaan (slurry) dan lubang penyaluran biogas yang terbentuk.

Beberapa jenis reaktor biogas yang sering digunakan :

\section{Reaktor Kubah Tetap (Fixed Dome)}

Reaktor ini disebut juga reaktor China. Dinamakan demikian karena reaktor ini dibuat pertama kali di China sekitar tahun 1930 an, kemudian sejak saat itu reaktor ini berkembang dengan berbagai model. Pada reaktor ini memiliki dua bagian yaitu digester sebagai tempat pencerna material biogas dan sebagai rumah bagi bakteri, baik bakteri pembentuk asam ataupun bakteri pembentuk gas metana. Bagian ini dapat dibuat dengan kedalaman tertentu menggunakan batu, batu bata atau beton. Strukturnya harus kuat karna menahan gas agar tidak terjadi kebocoran. Bagian yang kedua adalah kubah tetap (fixed- dome). Dinamakan kubah tetap karena bentuknya menyerupai kubah dan bagian ini merupakan pengumpul gas yang tidak bergerak (fixed). Gas yang dihasilkan dari bahan organik pada digester akan mengalir dan disimpan di bagian kubah.

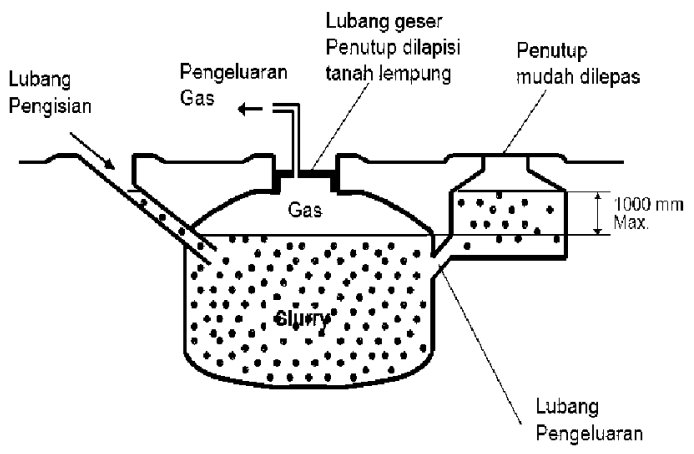

Gambar 1. Reaktor Kubah Tetap (Fixed Dome) Sumber: Waskito (2011)

2. Reaktor Terapung (Floating Drum Reactor)

Reaktor jenis terapung pertama kali dikembangkan di India pada tahun 1937 sehingga dinamakan dengan reaktor India. Memiliki bagian digester yang sama dengan reaktor kubah, 
perbedaannya terletak pada bagian penampung gas menggunakan peralatan bergerak menggunakan drum. Drum ini dapat bergerak naik turun yang berfungsi untuk menyimpan gas hasil fermentasi dalam digester. Pergerakan drum mengapung pada cairan dan tergantung dari jumlah gas yang dihasilkan.

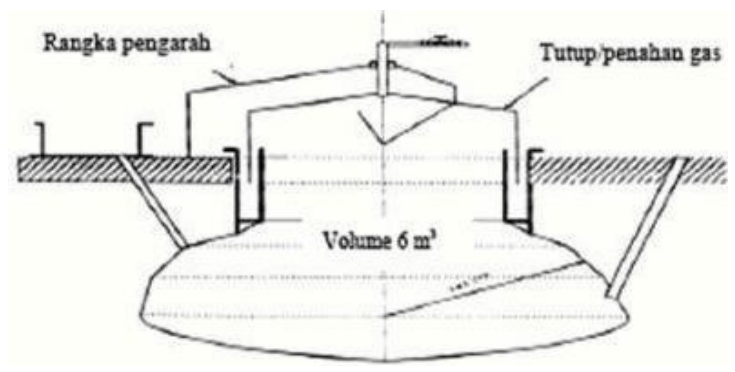

Gambar 2. Reaktor Terapung (Floating Drum Reactor) Sumber: Waskito (2011)

\section{Reaktor Balon (Ballon Reactor)}

Reaktor balon merupakan jenis reaktor yang banyak digunakan pada skala rumah tangga yang menggunakan bahan plastik sehingga lebih efisien dalam penanganan dan perubahan tempat biogas. Reaktor ini terdiri dari bagian yang berfungsi sebagai digester dan bagian penyimpan gas yang berhubungan tanpa sekat. Material organik terletak dibagian bawah karena memiliki berat yang lebih besar dibandingkan gas yang akan mengisi pada rongga atas.

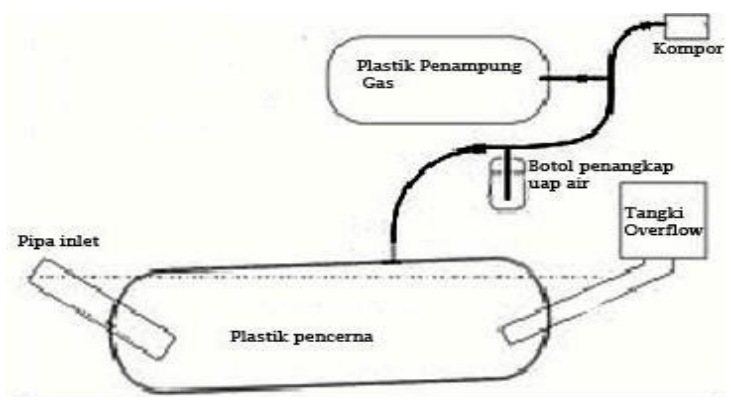

Gambar 3. Reaktor Ballon (Ballon Reactor) Sumber: Waskito (2011)

Berikut adalah kelebihan serta kekurangan dari reaktor yang akan dipergunakan seperti pada tabel 1.

Tabel 1. Kelebihan dan Kekurangan Reaktor

\begin{tabular}{|c|c|c|}
\hline $\begin{array}{c}\text { Jenis } \\
\text { Reaktor }\end{array}$ & Kelebihan & Kekurangan \\
\hline $\begin{array}{l}\text { Kubah } \\
\text { Tetap } \\
\text { (Fixed } \\
\text { Dome) }\end{array}$ & $\begin{array}{ll}\text { 1. } & \text { Sistem kedap } \\
\text { udara yang baik } \\
\text { 2. } \\
\text { Biaya } \\
\text { konstruksi lebih } \\
\text { murah } \\
\text { 3. Pemakaian } \\
\text { jangka panjang } \\
\text { 4. Perawatannya } \\
\text { lebih mudah } \\
\text { 5. Tipe batch } \\
\text { kontinyu }\end{array}$ & $\begin{array}{l}\text { 1. } \begin{array}{l}\text { Sering } \\
\text { terjadi } \\
\text { kehilangan }\end{array} \\
\text { gas } \\
\text { 2. Kontruksi } \\
\text { tetap tidak } \\
\text { bisa } \\
\text { dipindahkan }\end{array}$ \\
\hline
\end{tabular}

\begin{tabular}{|c|c|c|}
\hline $\begin{array}{l}\text { Terapung } \\
\text { (Floating } \\
\text { Drum) }\end{array}$ & $\begin{array}{ll}\text { 1. } & \text { Dapat } \\
\text { menunjukkan } \\
\text { volume gas yang } \\
\text { tersimpan dalam } \\
\text { drum } \\
\text { 2. Tekanan gasnya } \\
\text { konstan } \\
\text { 3. Temperatur } \\
\text { suhu stabil }\end{array}$ & $\begin{array}{l}\text { 1. Biaya } \\
\text { konstruksi } \\
\text { lebih mahal } \\
\text { 2. Mudah korosi } \\
\text { 3. Pemakaian } \\
\text { jangka } \\
\text { pendek }\end{array}$ \\
\hline Ballon & $\begin{array}{ll}\text { 1. } & \text { Biaya } \\
\text { konstruksi } \\
\text { relative rendah } \\
\text { 2. Tipe batch } \\
\text { kontinyu } \\
\text { 3. Dapat dibuat } \\
\text { dari bahan lain } \\
\text { 4. Mudah } \\
\text { dipindahkan }\end{array}$ & $\begin{array}{ll}\text { 1. } & \text { Tekanan } \\
\text { gas randah } \\
\text { 2. Sistem } \\
\text { tertutup } \\
\text { 3. Plastik } \\
\text { polyethylene } \\
\text { mudah } \\
\text { rusak }\end{array}$ \\
\hline
\end{tabular}

\section{c) Perancangan Desain Biodigester}

Ukuran tangki digester (reaktor) biogas tergantung dari jumlah, kualitas dan jenis bahan organik yang tersedia dan temperatur saat proses fermentasi anaerobik berlangsung. Jumlah bahan baku biogas yang dimasukkan dalam digester terdiri dari sampah organik dan air, sehingga pemasukan bahan baku sangat tergantung dengan seberapa banyak air yang dimasukkan kedalam digester. Pencampuran bahan organik untuk sampah organik dengan air dibuat perbandingan antara 1:1 dan 2:1 berdasarkan unit volume (air dan sampah organik dalam volume yang sama). (Didit Waskito,2011)

Dibawah ini gambar bentuk penampang silinder digester anaerob (Cylindrical Shaped BioGas Digester Body) dengan penjelasan sebagai berikut:

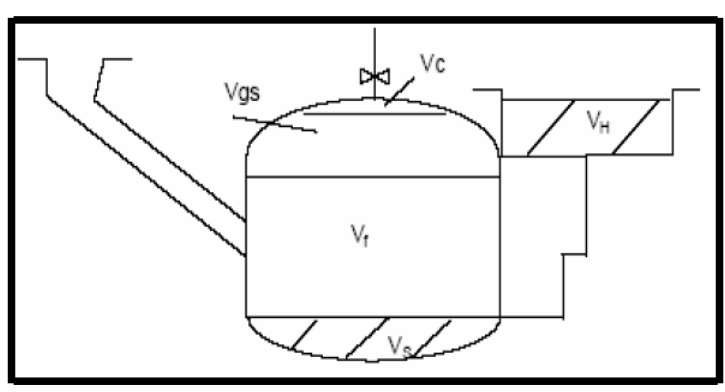

Gambar 4. Penampang Digester Biogas Silinder

Keterangan :

$V_{c}=$ Volume ruangan penampung gas

Vgs $=$ Volume ruangan penyimpanan gas

$\mathrm{Vf}=$ Volume ruangan fermentasi

$\mathrm{V}_{\mathrm{H}}=$ Volume ruangan hidrolik (hydraulic chamber)

$\mathrm{Vs}=$ Volume penampung lumpur (sludge layer)

\section{Total Volume Digester $(\mathbf{V})=\mathbf{V c}+\mathrm{Vgs}+\mathrm{Vf}+$ Vs..1)}

Berdasarkan jumlah volume bahan baku (Q), maka dapat ditentukan volume kerja digester (working volume digester) yang merupakan penjumlahan volume ruangan penyimpanan (Vgs) dan volume ruangan fermentasi (Vs). 
Volume kerja digester $=\mathbf{V g s}+\mathbf{V f}$

Dimana : Vgs + Vf $=\mathbf{Q} \times$ HRT (waktu digestifikasi)

Untuk mendesain tangki digester biogas, dapat dilihat pada gambar dimensi geometrical tangki digester di bawah ini :

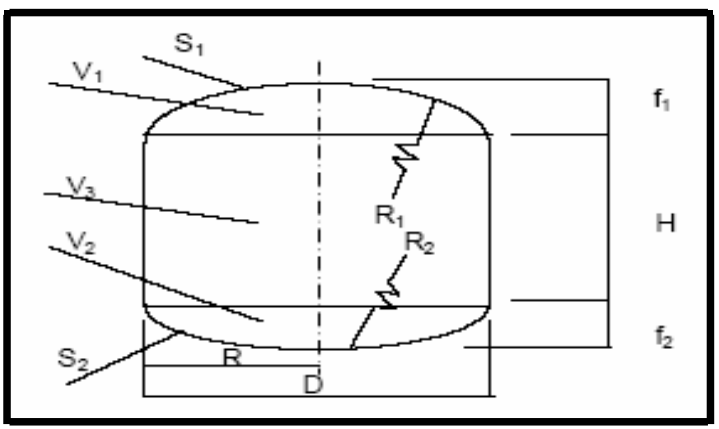

Gambar 5. Dimensi Geometrikal Tangki Digester

Berdasarkan gambar dimensi geometrical tangki digester diatas berlaku ketentuan bentuk geometrical ruangan-ruangan digester sebagai berikut :

Volume penampung lumpur keluaran dari reaktor, $\mathrm{V}_{\mathrm{pl}}$ :

$\mathrm{Vpl}=\mathrm{p} \times \mathrm{Lxt}$

Dimana, $\mathrm{p}$ : panjang $(\mathrm{m})$

$$
\begin{aligned}
& \mathrm{L} \text { : lebar }(\mathrm{m}) \\
& \mathrm{t} \text { : tinggi }(\mathrm{m})
\end{aligned}
$$

\section{d) Penentuan Kapasitas Biogas (Produks} Gas Metan)

Biogas dapat digunakan sebagai bahan bakar dan sebagai sumber energi alternatife untuk penggerak generator pembangkit tenaga listrik serta menghasilkan energi panas. Karakteristik biogas adalah sebagai berikut:

1. Biogas kira-kira memiliki berat $20 \%$ lebih ringan dibandingkan udara dan memiliki suhu pembakaran antara $650-750^{\circ} \mathrm{C}$.

2. Biogas tidak berbau dan berwarna yang apabila dibakar akan menghasilkan nyala api biru cerah seperti gas LPG.

3. $1 \mathrm{~m}^{3}$ gas metan setara dengan $11,17 \mathrm{kWh}$.

Biogas yang dihasilkan apabila dimanfaatkan memiliki kesetaraan energi dengan sumber energi lain adalah sebagai berikut :

Tabel 2. Nilai Kesetaraan $1 \mathrm{~m}^{3}$ Biogas Dengan Energi Lainnya

\begin{tabular}{|c|l|}
\hline Volume & \multicolumn{1}{|c|}{ Kesetaraan } \\
\hline \multirow{4}{*}{$1 \mathrm{~m}^{3}$ Biogas } & $0,46 \mathrm{~kg}$ LPG \\
& 0,62 liter minyak tanah \\
& $3,5 \mathrm{~kg}$ kayu bakar \\
& 0,62 minyak solar \\
\hline
\end{tabular}

Sumber : Wahyuni, 2008

Langkah-langkah menentukan produksi biogas , yaitu

1. Penentuan data potensi bahan baku biogas
2. Perhitungan jumlah dari total solid (TS) volate solid (VS) dalam proses anaerobic digestion.

TS $=3,095 \%$ x Ps Kg

$\mathrm{VS}=85 \% \times \mathrm{TS} \mathrm{Kg}$

Keterangan : $\mathrm{Ps}=$ data potensi bahan baku biogas $\mathrm{TS}=$ total solid $(\mathrm{Kg} / \mathrm{hari})$ $\mathrm{VS}=$ volatile solid $(\mathrm{Kg} / \mathrm{hari})$

\section{Perhitungan jumlah volume gas metan}

Vgm $=$ Komposisi Biogas $\% x$ VS $\mathrm{m}^{3} \ldots 6$ )

Keterangan : Vgm = jumlah volume gas metan VS = volatile solid (Kg/hari)

Penting diperhatikan bahwa konsentrasi TS hendaknya dijaga tidak lebih dari 15\% karena akan menghambat metabolism. Pada saat memasukkan bahan baku organik ke dalam biodigester wajib ditambahkan sejumlah air. Fungsi air disini selain untuk mempertahankan TS $<15 \%$, juga untuk mempermudah proses pencampuran dan proses mengalirnya material organik ke dalam biodigester. Fungsi lainnya adalah untuk mempermudah aliran gas yang terbentuk dibagian bawah dapat mengalir ke bagian atas biodigester (Suyitno,2009).

Tabel 3. TS Beberapa Material Organik Selain Kotoran Hewan

\begin{tabular}{|l|c|c|}
\hline Material & TS (\%) & VS (\%) \\
\hline Jerami Padi & 89 & 93 \\
\hline Jerami Gandum & 82 & 94 \\
\hline Jerami Jagung & 80 & 91 \\
\hline Rumput Segar & 24 & 89 \\
\hline Bagase & 65 & 78 \\
\hline Sisa Sayuran & 12 & 86 \\
\hline
\end{tabular}

Sumber : Suyitno, 2009

\section{e) Manfaat dari Teknologi Biodigester}

Hasil utama dari teknologi biodigester adalah biogas yang berupa gas methan dan gas lainnya yang dapat dimanfaatkan untuk mendukung kehidupan masyarakat. Manfaat biogas yang tidak langsung adalah menjaga kelestarian lingkungan hidup dan konservasi sumber daya alam.

Manfaat langsung penggunaan biogas adalah sebagai berikut :

a. Sebagai sumber energi untuk memasak

Biogas yang diproduksi oleh satu unit instalasi biodigester dapat digunakan sebagai sumber energi untuk memasak. Untuk biogas yang menggunakan bahan baku kotoran sapi menghasilkan gas methan yang lebih besar dibandingkan sampah organik jenis sayuran.

b. Sebagai sumber energi untuk penerangan Biogas sebagai sumber energi untuk penerangan yaitu berupa lampu. Lampu yang digunakan adalah lampu petromaks yang dimodifikasi. Pengalaman di lapangan menunjukkan bahwa pemanfaatan biogas untuk memasak sekaligus sebagai sumber penerangan, biasanya dilakukan bila jumlah kotoran sapi paling sedikit 6 ekor dengan 
model digester permanen bata kapasitasnya 9 $\mathrm{m}^{3}$ (Muryanto, 2006)

c. Penghasil pupuk organik siap pakai

Manfaat lain adalah dapat menyediakan pupuk organik siap pakai dalam jumlah banyak sesuai dengan kapasitas digester yang dibangun dan bahan baku yang digunakan. Kotoran ternak yang telah diproses dalam biodigester dapat langsung digunakan sebagai pupuk organik dan kaya akan kandungan Nitrogen (N). Sedangkan sampah organik dari limbah rumah tangga dapat menghasilkan pupuk organik padat dan pupuk cair (Suriawiria, 2005).

Dari manfaat teknologi biodigester tersebut dari segi ekonomisnya dapat dijadikan nilai jual yang menguntungkan bagi masyarakat.

\section{f) Penentuan Sistem Operasional \\ Pengelolaan Sampah}

Sistem operasi pengelolaan sampah meliputi jam kerja pengolahan sampah dan perhitungan tenaga kerja. Perhitungan sistem operasional TPST berdasarkan acuan perhitungan yang digunakan oleh Dinas Pekerjaan Umum Kabupaten Pati.

1. Perhitungan estimasi waktu pengolahan sampah

$$
\text { Waktu }=\frac{\text { Jumlah total sampah }}{\text { kecepatan pekerja }}
$$

2. Perhitungan tenaga kerja pemilihan sampah manual

Tenaga Kerja $=\frac{\text { Beban Kerja }}{\text { Kapasitas Pekerja } \mathrm{x} \text { Kecepatan Pekerja }}$

3. Perhitungan tenaga kerja alat pencacah

Tenaga Kerja $=\frac{\text { Beban Kerja }}{\text { Waktu untuk } 1 \text { org } \mathrm{x} \text { waktu operasi }}$

g) Penentuan Pay Back Period (PBP)

Rumus yang digunakan berdasarkan modul materi mengenai analisis keputusan investasi oleh Ervita Safitri, S.E., M.Si

1. Perhitungan laba

Laba per bulan=biaya pemasukkan - biaya pengeluaran

2. Perhitungan untuk pay back period (PBP) pay back period $(\mathrm{PBP})=\frac{\text { Biaya Investasi }}{\text { Laba }}$

\section{h) Konservasi Lingkungan}

a. Pengertian Konservasi

Secara harfiah konservasi berasal dari bahasa Inggris yaitu dari kata "Conservation" yang berati pelestarian atau perlindungan. Konsevasi adalah suatu upaya yang dilakukan oleh manusia untuk dapat melestarikan alam, konservasi bisa juga disebut dengan pelestarian ataupun perlindungan.

\section{b. Tujuan Konservasi}

Tujuan dari Konservasi Lingkungan adalah:

1. Mewujudkan kelestarian sumber daya alam baik fisik dan hayati untuk menciptakan ekosistem yang seimbang. ekosistem yang seimbang akan mendukung adanya peningkatan kesejahteraan dan kualitas kehidupan manusia.

2. Melestarikan pemanfaatan dan kemampuan sumberdaya alam fisik dan hayati serta ekosistem agar serasi dan seimbang.

c. Manfaat Konservasi

Adapun manfaat konservasi lingkungan adalah sebagai berikut:

1. Manfaat yang bersifat edukatif

2. Sebagai wahana pengembangan pengetahuan alam yang didukung dengan terapan teknologi yang berwawasan lingkungan

3. Sebagai hidrologis pendukung kehidupan

4. Untuk menciptakan iklim yang baik dan seimbang

5. Untuk menciptakan lingkungan yang sehat.

\section{METODOLOGI PENELITIAN}

Dalam perencanaan desain Tempat Pembuangan Sampah Terpadu (TPST) dilingkungan kelurahan Petir Tangerang diperlukan suatu metode pelaksanaan yang sistematis mulai dari awal sampai selesainya, sehingga diperoleh hasil yang optimal dan sesuai dengan tujuan pekerjaan. Tahapan perencanaan desain fungsi bangunan TPST dan perencanaan alur pengelolaan sampah meliputi :

\section{A. Tahap Persiapan}

Dalam tahap ini dilakukan persiapan peralatan yang akan digunakan dalam sampling timbulan sampah, dan pengukuran topografi

\section{B. Tahap Survey dan Pengumpulan Data}

Survey yang dilakukan untuk memperoleh data-data primer dan data-data sekunder. Pengumpulan data diperoleh melalui metode observasi. Observasi kebutuhan data dilakukan dengan wawancara dengan pengelola TPST GEMPEL-BEHI di Kelurahan Petir Kecamatan Cipondoh Kota Tangerang untuk mengetahui luas lahan TPST, Volume sampah yang masuk, sistem pengolahan sampah yang sudah berjalan, dan perencanaan TPST yang sedang dikembangkan

\section{Tahap Analisa}

Tahap ini memaparkan tentang analisa yang dilakukan sebagai dasar perencanaan dan perancangan desain fungsi bangunan TPST GEMPEL-BEHI serta alur pengelolaan sampah. Analisa data digunakan untuk menganalisa data yang ada untuk diolah. Dalam penelitian ini, data yang akan dianalisa adalah data volume sampah dan luas lahan TPST. Kedua data tersebut akan digunakan untuk membuat desain fungsi ruang bangunan dan konsep alur pengelolaan sampah di TPST. 


\section{Tahap Perancangan}

1. Pembuatan Gambar Desain fungsi Bangunan TPST

Dalam pembuatan gambar desain fungsi ruang pada bangunan TPST akan dilakukan beberapa tahapan sebagai berikut :

- Penentuan Kriteria Desain

Penentuan kriteria desain dilakukan untuk menentukan kriteria dasar perencanaan fungsi ruang bangunan TPST yang akan direncanakan sebagai dasar perencanaan yang berdasarkan atas analisa data volume sampah.

- Perancangan

Perancangan meliputi rancangan fungsional bangunan pengolahan sampah dan rancangan struktural untuk menentukan tata letak bangunan. Analisa teknik dilakukan untuk menghitung ukuran bangunan sesuai volume yang ditentukan. Selain itu juga perlu dipertimbangkan untuk kenyamanan kerja.

- Pembuatan Gambar Teknik

Tahap ini adalah membuat gambar desain atau gambar teknik dari TPST yang direncanakan. Dalam proses penggambaran menggunakan software autocad 2013

2. Perencanaan Alur Pengelolaan Sampah TPST

Dalam tahap ini dilakukan analisa sesuai dengan data yang didapatkan. Hal ini bertujuan agar mendapatkan konsep dalam perencanaan alur pengelolaan sampah di TPST GEMPEL-BEHI sesuai dengan volume sampah pada kondisi eksisting yang akan digunakan. Sehingga kedepannya tidak ada penumpukkan sampah yang terjadi akibat belum adanya pengelolaan sampah yang cukup baik pada TPST GEMPEL- BEHI.

\section{HASIL DAN PEMBAHASAN}

\section{a) Alur Pengelolaan Sampah Yang \\ Direncanakan}

Total volume sampah yang diproduksi oleh TPST GEMPEL-BEHI adalah $87,5 \mathrm{~m}^{3} /$ hari setara dengan 17,5 ton/hari. Sampah tersebut nantinya akan masuk pada area pemilahan untuk sampah organik dan sampah anorganik. Berikut ini adalah alur pengolahan sampah yang akan direncanakan untuk mengoptimalkan pengolahan sampah.

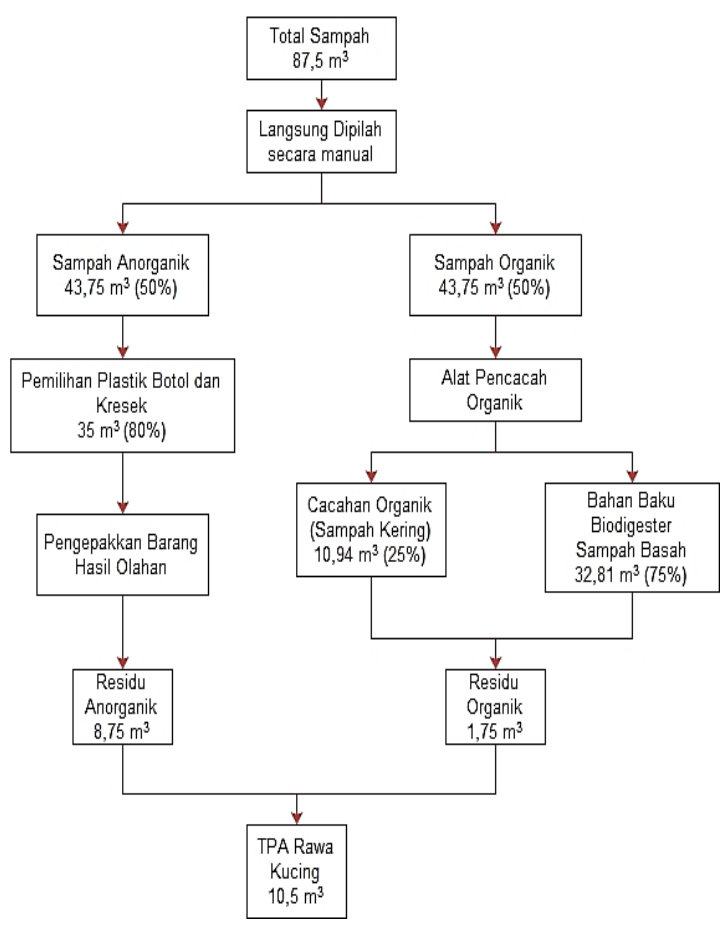

Sumber : Hasil Pengolahan Data

Gambar 6. Alur Pengolahan Sampah Setelah Pengembangan

Berdasarkan gambar 6 . dapat dijelaskan bahwa volume sampah yang masuk ke TPST GEMPEL-BEHI sebanyak $87,5 \mathrm{~m}^{3} /$ hari memerlukan tenaga kerja berjumlah 2 orang. Tugas dari tenaga kerja ini adalah memilah dan mengolah sampah sebesar $15 \%$ dari total sampah yang dihasilkan. Pengambilan $15 \%$ dari total sampah dikarenakan kurang adanya sumber daya manusia untuk mengelola semua sampah yang dihasilkan. Proses pemilahan berlangsung mulai dari pukul 08.00 WIB sampai dengan pukul 12.00 WIB. Dari pemilahan ini didapatkan sampah organik dan sampah anorganik yang masih dapat dimanfaatkan secara ekonomis. Dan sisa dari sampah tersebut dibawa oleh truk pengangkut sampah dari Dinas kebersihan kota Tangerang memulai proses pengangkutan dari pukul 08.00 WIB sampai dengan selesai. Truk sampah ini mengangkut sampah dari TPST ke TPA Rawa Kucing dengan membawa $85 \%$ sisa sampah.

\section{b) Sistem Kerja Biodigester}

Cara kerja biodigester dapat dilihat pada diagram alir dibawah ini : 


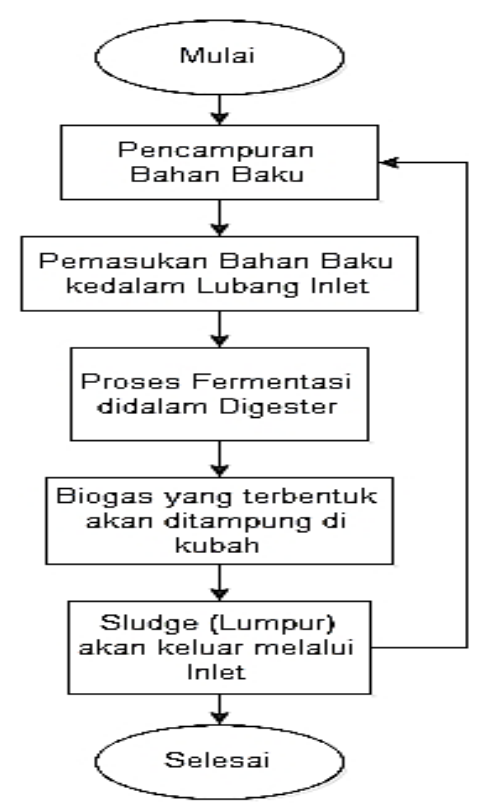

Gambar 7. Cara Kerja Biodigester

Cara pengoperasian Biodigester seperti terjabar dalam Seri Bioenergi Pedesaan Direktorat Pengolahan Hasil Pertanian tahun 2009 sebagai berikut :

1. Membuat campuran sampah organik dan air dengan perbandingan $1: 1$ atau $1: 2$ sebagai bahan baku. Jika ingin proses pembusukan dalam digester berlangsung cepat bisa ditambahkan pupuk c4 dengan perbandingan $1: 2$

2. Memasukkan bahan baku ke dalam digester melalui lubang pengisian (inlet) hingga bahan yang dimasukkan ke digester ada sedikit yang keluar melalui lubang pengerluaran (outlet), selanjutnya akan berlangsung proses produksi biogas di dalam digester.

3. Di dalam Digester terjadi fermentasi sehingga terjadi biogas. Terjadinya gas berkisar antara 3 - 4 hari, dan paling lama 7 hari. Jika lebih dari 7 hari gas belum keluar maka perlu diambil tindakan. Biogas sudah terbentuk dapat digunakan sebagai bahan bakar, kompor biogas dapat dioperasikan.

4. Biogas yang terjadi akan terkumpul di kubah yang terbuat dari pasangan beton hingga menjadi jenuh.

5. Proses terjadinya biogas akan terus berlangsung hingga hari ke 50 dengan puncaknya pada hari ke 35. Akibatnya biogas akan menekan slurry (lumpur) yang akan keluar menuju Outlet. Selanjutnya slurry telah menjadi Bio-slurry dan siap digunakan sebagai pupuk organik. Bio-slurry sudah tidak berbau dan aman digunakan sebagai pupuk.

6. Sisa pengolahan bahan biogas berupa sludge (lumpur) secara otomatis akan keluar dari lubang pengeluaran (outlet) setiap kali dilakukan pengisian bahan biogas.

c) Potensi Hasil Olahan Biodigester

Setelah mendapatkan model suatu reaktor biogas pada pengembangan TPST GEMPEL-BEHI yang disesuaikan dengan lahan eksisting dan volume sampah, maka akan dilakukan analisa mengenai potensi biogas. Pada prinsipnya teknologi biogas adalah teknologi yang memanfaatkan proses fermentasi (pembusukan) dari sampah organik secara anaerob (tanpa udara) oleh bakteri mektan sehingga dihasilkan gas metan. Gas metan memiliki sifat mudah terbakar karena mengandung satu atom $C$ dan 4 atom sehingga dihasilkan energi panas. Bahan organik yang bisa digunakan sebagai bahan baku adalah sampah organik, limbah yang sebagian besar terdiri dari jumlah kotoran hewan dan potongan-potongan kecil sisa-sisa tanaman, seperti jerami dan sebagainya serta air yang cukup banyak.

Dari gambar 6. didapat jumlah volume sampah organik yang akan digunakan untuk bahan baku biodigester adalah $32,81 \mathrm{~m}^{3} /$ hari yang setara dengan 6,56 ton/hari atau $6560 \mathrm{~kg} / \mathrm{hari}$.

Dari tabel 3. telah diketahui nilai dari TS dan VS untuk sampah sisa sayuran adalah :

$\%$ TS $($ total solid $)=12 \%$

$\%$ VS (volatile solid $=86 \%$

Pengertian total solid content (TS) adalah jumlah materi padatan yang terdapat dalam bahan organik selama proses digester terjadi dan ini mempengaruhi lamanya proses pencernaan/ digester (HRT) bahan organik.

Selanjutnya volatile solid (VS) adalah berat saat bagian padatan bahan organik yang hilang terbakar (menguap dan mengalami proses gasifikasi) atau potensi produksi biogas.

Berikut ini merupakan perkiraan produksi biogas untuk beberapa jenis kotoran :

Tabel 4. Perkiraan Produksi Biogas dari Beberapa Jenis Kotoran

\begin{tabular}{|l|c|}
\hline Jenis kotoran & $\begin{array}{c}\text { Perkiraan produksi biogas } \\
\left(\mathbf{m}^{\mathbf{3}} \mathbf{)} \text { per kg kotoran }\right.\end{array}$ \\
\hline Sapi/Kerbau & $0,023-0,04$ \\
\hline Babi & $0,04-0,059$ \\
\hline Unggas & $0,065-0,116$ \\
\hline Manusia & $0,02-0,028$ \\
\hline Kuda & $0,02-0,035$ \\
\hline $\begin{array}{l}\text { Domba/ } \\
\text { Kambing }\end{array}$ & $0,01-0,031$ \\
\hline Jerami padi & $0,017-0,028$ \\
\hline Jerami jagung & $0,035-0,048$ \\
\hline Rumput & $0,028-0,055$ \\
\hline Rumput gajah & $0,033-0,056$ \\
\hline Bagase & $0,014-0,019$ \\
\hline Sayuran & $\mathbf{0 , 0 3 - 0 , 0 4}$ \\
\hline
\end{tabular}

Sumber : Suyitno dkk, 2010

Berdasarkan tabel 4. potensi biogas untuk sayuran adalah :

Volume Produksi Biogas

$($ VBS $)=0.04 \mathrm{~m}^{3} / \mathrm{kg} \times 6560 \mathrm{~kg} / \mathrm{hari}=262,4 \mathrm{~m}^{3} /$ hari VS $=3,9 \mathrm{~kg} /$ hari $\times 262,4 \mathrm{~m}^{3} /$ hari $=1023,36 \mathrm{~kg} /$ hari 
Laju produksi gas tiap $\mathrm{m}^{3}$ per hari $(\mathrm{K})$ adalah :

Volume produksi biogas $=\mathrm{K} \times \mathrm{VS}$

$\mathrm{K}=$ Volume produksi biogas : VS

$=262,4 \mathrm{~m}^{3} /$ hari : $1023,36 \mathrm{~kg} /$ hari

$=0,25 \times 100$

$=25 \%$

\section{d) Perhitungan Produksi Gas Metan}

Dengan diketahui nilai produksi biogas (VBS) sebesar $262,4 \mathrm{~m}^{3} /$ hari dan dengan menggunakan tabel 5. maka dapat diketahui produksi gas metan (VGM) adalah :

$\mathrm{VGM}=54 \% \times \mathrm{VBS}$

$=54 \% \times 262,4 \mathrm{~m}^{3} /$ hari

$=141,7 \mathrm{~m}^{3} /$ hari

Tabel 5. Komposisi Biogas (\%) Kotoran Ternak Dicampur dengan Sampah Rumah Tangga

\begin{tabular}{|l|c|c|}
\hline \multirow{2}{*}{ Jenis Gas } & \multicolumn{2}{|c|}{ Biogas } \\
\cline { 2 - 3 } & $\begin{array}{l}\text { Kotoran } \\
\text { sapi }\end{array}$ & $\begin{array}{c}\text { Campuran kotoran } \\
\text { + sampah organik }\end{array}$ \\
\hline Metan (CH4) & 65,7 & $54-70$ \\
\hline $\begin{array}{l}\text { Karbon dioksida } \\
\text { (CO2) }\end{array}$ & 27,0 & $45-57$ \\
\hline Nitrogen (N2) & 2,3 & $0,5-3,0$ \\
\hline $\begin{array}{l}\text { Karbon monoksida } \\
\text { (CO) }\end{array}$ & 0 & 0,1 \\
\hline Oksigen (O2) & 0,1 & 6,0 \\
\hline Propena (C3H8) & 0,7 & - \\
\hline Hidrogen sulfida(H2S) & - & Sedikit \\
\hline Nilai kalor (kkal/m2) & 6513 & $4800-6700$ \\
\hline
\end{tabular}

Sumber : Tesis DIdit Waskita, 2011

\section{e) Perhitungan Potensi Energi Listrik yang Dihasilkan}

Dengan diketahui volume gas metan yang dihasilkan yaitu $141,7 \mathrm{~m}^{3}$ /hari, dan Faktor Konversi (FK) berdasarkan tabel $2.3\left(1 \mathrm{~m}^{3}\right.$ gas metan setara $11,72 \mathrm{kWh}$ ), sehingga potensi energi listrik yang dihasilkan adalah :

$$
\begin{aligned}
\mathrm{E} & =\mathrm{VGM} \times \mathrm{FK} \\
& =141,7 \times 11,72 \\
& =1.660,72 \mathrm{kWh} / \text { hari }
\end{aligned}
$$

Jadi dari perhitungan data potensi yang ada didapat hasil sebagai berikut:

Tabel 6. Data Potensi Biogas dari Pengolahan Data

\begin{tabular}{|c|l|c|}
\hline No & \multicolumn{1}{|c|}{ Jenis Proses Perhitungan } & $\begin{array}{c}\text { Hasil } \\
\text { Perhitungan }\end{array}$ \\
\hline 1. & Potensi Sisa Sayuran (Q) & $6.560 \mathrm{~kg} / \mathrm{hari}$ \\
\hline 2. & $\begin{array}{l}\text { Perhitungan jumlah dari volatile } \\
\text { solid (VS) }\end{array}$ & $\begin{array}{c}1.023,36 \\
\mathrm{~kg} / \mathrm{hari}\end{array}$ \\
\hline 3. & $\begin{array}{l}\text { Perhitungan jumlah volume } \\
\text { produksi biogas (VBS) }\end{array}$ & $262,4 \mathrm{~m}^{3} / \mathrm{hari}$ \\
\hline
\end{tabular}

\begin{tabular}{|c|l|c|}
\hline 4. & $\begin{array}{l}\text { Perhitungan jumlah volume gas } \\
\text { metan (VGM) }\end{array}$ & $141,7 \mathrm{~m}^{3} /$ hari \\
\hline 5. & $\begin{array}{l}\text { Perhitungan potensi energi listrik } \\
(\text { E) }\end{array}$ & $\begin{array}{c}1.660,72 \\
\mathrm{kWh} / \text { hari }\end{array}$ \\
\hline
\end{tabular}

Sumber : Hasil Pengolahan Data

\section{f) Perancangan Ukuran Digester}

Ukuran tangki digester (reaktor) biogas tergantung dari jumlah, kualitas dan jenis bahan organik yang tersedia dan temperatur saat proses fermentasi anaerobik berlangsung. Jumlah bahan baku biogas yang dimasukkan dalam digester terdiri dari sampah organik dan air, sehingga pemasukan bahan baku sangat tergantung dengan seberapa banyak air yang dimasukkan kedalam digester. Pencampuran bahan organik untuk sampah organik dengan air dibuat perbandingan antara 1:1 dan 2:1 berdasarkan unit volume (air dan sampah organik dalam volume yang sama).

Dari pengolahan data pada gambar 8. didapat jumlah volume sampah organik yang akan digunakan untuk biodigester adalah $32,81 \mathrm{~m}^{3} /$ hari yang setara dengan 6,56 ton/hari atau 6.560 $\mathrm{kg} / \mathrm{hari}$. Untuk mendapatkan bahan baku biogas adalah sampah organik yang telah dicacah dicampur dengan air dengan perbandingan 1:1 sehingga ;

Jumlah air yang ditambahkan $=$ jumlah potensi sampah organik $=6.560 \mathrm{~kg} / \mathrm{har}$

Maka $(Q)=13.120 \mathrm{~kg} / \mathrm{hari}$

Waktu penyimpanan (HRT) tergantung pada temperatur lingkungan dan temperatur biodigester. Dengan kondisi tropis seperti di Indonesia, pada suhu $25-35^{\circ} \mathrm{C}$, waktu digestifikasi adalah kira-kira 10 hari, waktu digestifikasi yang pendek dapat mengurangi volume digester dan sebaliknya yang panjang dapat menambah volume digester. Jika digunakan bahan tambahan seperti pupuk C4, waktu digestifikasi bisa menjadi lebih pendek yaitu 4 hari. Maka dengan persamaan 2.3 dan 2.4 dapat ditentukan volume kerja digester, dimana volume kerja digester merupakan penjumlahan volume ruangan digestifikasi (Vf) dan volume penyimpanan (Vgs) yaitu :

$$
\begin{aligned}
& \text { Volume Kerja Digester } \\
& =\mathrm{Vgs}+\mathrm{Vf}=\mathrm{Q} \times \mathrm{HRT} \\
& =13.120 \times 10 \text { hari } \\
& =131.200 \mathrm{Kg}
\end{aligned}
$$

Karena kurang lebih $80 \%$ dari total $\mathrm{Q}$ (bahan baku) adalah air maka kita asumsikan massa jenis $\mathrm{Q}($ bahan baku $) \approx$ massa jenis air $\left(1000 \mathrm{~kg} / \mathrm{m}^{3}\right)$

$$
\begin{aligned}
& V=m / \rho \\
& =(V g s+V f) / \rho \\
& =131.200 \mathrm{~kg} / 1.000 \mathrm{~kg} / \mathrm{m}^{3} \\
& =131,2 \mathrm{~m}^{3}
\end{aligned}
$$

Berdasarkan asumsi persamaan geometrikal untuk ukuran tangki digester maka diperoleh : $\mathrm{Vgs}+\mathrm{Vf}=80 \% \mathrm{~V}$ atau

$\mathrm{V}=(\mathrm{Vgs}+\mathrm{Vf}) / 0,8$

$V=131,2 \mathrm{~m}^{3} / 0,8$

$\mathrm{V}=164 \mathrm{~m}^{3}$

Volume ruangan penampungan gas $(\mathrm{Vc})=5 \% \times \mathrm{V}$

$=5 \% \times 164 \mathrm{~m}^{3}$

$=8,2 \mathrm{~m}^{3}$ 
Volume lapisan penampungan lumpur (Vs)

$=15 \% \times \mathrm{V}$

$=15 \% \times 164 \mathrm{~m}^{3}$

$=24,6 \mathrm{~m}^{3}$

Volume penyimpanan $(\mathrm{Vgs})=0,5(\mathrm{Vgs}+\mathrm{Vf}+\mathrm{Vs}) \mathrm{K}$ $\mathrm{K}$ merupakan nilai laju produksi gas tiap $\mathrm{m} 3$ per hari, nilai $\mathrm{K}$ untuk sayuran adalah 0.04 didapatkan nilai $\mathrm{K}=25 \%$

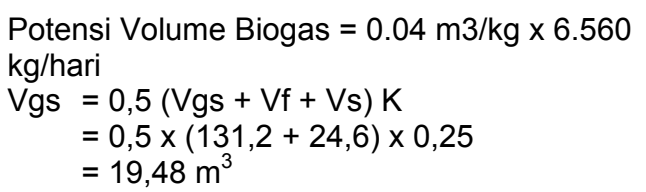

Dari nilai Vgs $=19,48 \mathrm{~m}^{3}$ sehingga dapat diketahui nilai $\mathrm{Vf}$, yaitu :

$\mathrm{Vgs}+\mathrm{Vf}=164$

$\mathrm{Vf}=164-19,48$

$\mathrm{Vf}=144,52 \mathrm{~m}^{3}$

Dari asumsi geometris juga diketahui $\mathrm{Vgs}=$ $\mathrm{VH}=19,48 \mathrm{~m}^{3}$, artinya biogas akan menempati seluruh ruang penyimpanan gas (fixed drum digester type) sesuai volume gas yang dihasilkan. Sehingga diketahui volume masing-masing bagian digester yaitu :

1. Volume Total Digester $(V)=164 \mathrm{~m}^{3}$

2. Volume Ruangan Penampung Gas $(\mathrm{Vc})=8,2 \mathrm{~m}^{3}$

3. Volume Ruangan Penyimpanan (Vgs) $=19,48$ $\mathrm{m}^{3}$

4. Volume Ruangan Fermentasi $(\mathrm{Vf})=144,52 \mathrm{~m}^{3}$

5. Volume Ruangan Hidrolik $(\mathrm{VH})=19,48 \mathrm{~m}^{3}$

6. Lapisan Penampung Lumpur $(\mathrm{Vs})=24,6 \mathrm{~m}^{3}$

f) Menghitung Diameter Digester (D)

$\mathrm{D}=1,3078 \times \mathrm{V}^{1 / 3}$ dengan $\mathrm{V}=164 \mathrm{~m}^{3}$

$=1,3708 \times 164^{1 / 3}$

$=7,5 \mathrm{~m}$

Dengan diketahui $\mathrm{D}=7,5 \mathrm{~m}$, maka berturutturut dapat diketahui ukuran-ukuran dari digester, sebagaimana tabel 7 . berikut :

Tabel 7. Dimensi Ukuran Rancangan Digester

\begin{tabular}{|c|c|c|c|c|c|}
\hline Dimensi & $\begin{array}{c}\text { Rumus } \\
\text { Dimensi }\end{array}$ & Nilai & Dimensi & $\begin{array}{c}\text { Rumus } \\
\text { Dimensi }\end{array}$ & Nilai \\
\hline V1 & $0,0827 \times \mathrm{D}^{3}$ & $34,89 \mathrm{~m}^{3}$ & $\mathrm{f} 1$ & $\mathrm{D} / 5$ & $1,5 \mathrm{~m}$ \\
\hline $\mathrm{V} 2$ & $0,05011 \times \mathrm{D}^{3}$ & $21,14 \mathrm{~m}^{3}$ & $\mathrm{f} 2$ & $\mathrm{D} / 8$ & $0,94 \mathrm{~m}$ \\
\hline $\mathrm{V} 3$ & $0,3142 \times \mathrm{D}^{3}$ & $132,55 \mathrm{~m}^{3}$ & $\mathrm{~S} 1$ & $0,911 \times \mathrm{D}^{2}$ & $51,24 \mathrm{~m}^{2}$ \\
\hline $\mathrm{R} 1$ & $1,0625 \times \mathrm{D}$ & $7,97 \mathrm{~m}$ & $\mathrm{~S} 2$ & $0,8345 \times \mathrm{D}^{2}$ & $46,94 \mathrm{~m}^{2}$ \\
\hline $\mathrm{R} 2$ & $0,725 \times \mathrm{D}$ & $5,44 \mathrm{~m}$ & & & \\
\hline
\end{tabular}

Sumber : Hasil Pengolahan Data

\section{g) Menghitung Tangki Efektif Digester $(\mathrm{H})$}

Dengan melakukan pendekatan dengan volume tabung, maka :

$$
\begin{aligned}
V \text { tabung } & =1 / 4 \pi D^{2} \\
V 3 & =1 / 4 \times 3,142 \times D^{2} \times H \text { untuk } \\
V 3 & =132,55 \mathrm{~m}^{3}
\end{aligned}
$$

$$
\begin{aligned}
H & =132,55 /(1 / 4 \times 3,142 \times \\
& =3 \mathrm{~m}
\end{aligned}
$$

Berdasarkan dimensi ruangan digester yang telah diketahui, berikut gambar rancangan digester untuk sampah organik yang ada di TPST GEMPEL-BEHI.

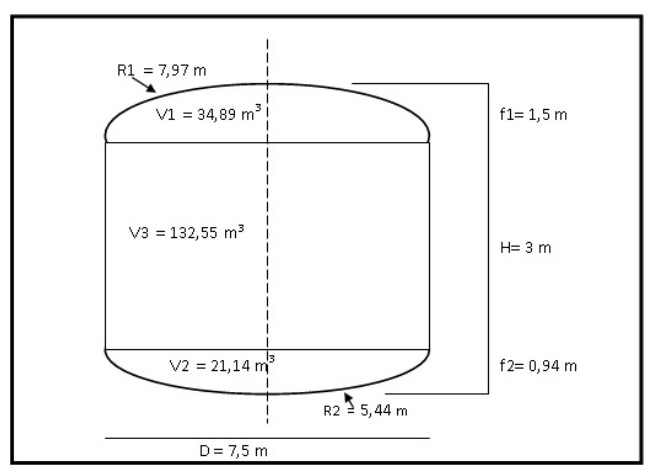

Gambar 8. Dimensi Rancangan Digester

h) Perhitungan Perkiraan Tenaga Kerja

Perhitungan tenaga kerja disesuaikan dengan penambahan alat dan jumlah sampah. Perhitungan terdiri dari perhitungan tenaga kerja untuk pemilahan sampah, alat pencacah sampah organik, dan pengepakkan sampah plastik layak jual. Rumus yang digunakan berdasarkan acuan perhitungan yang digunakan oleh Dinas Pekerjaan Umum Kabupaten Pati mengenai sistem penanganan sampah pada TPA Kabupaten Pati.

1. Perkiraan Tenaga Kerja Pemilihan Sampah Manual.

$\begin{array}{lr}\text { Beban kerja } & : 87,5 \mathrm{~m}^{3} \\ \text { Kecepatan Pekerja } & : 1 \mathrm{~m}^{3} / \mathrm{jam} \\ \text { Kapasitas Pekerja } & : 6 \mathrm{jam}\end{array}$

Perhitungan :

Tenaga Kerja $=\frac{\text { Beban Kerja }}{K a p a s t a s ~ P e k e r j a x ~}$

Tenaga Kerja $=\frac{87,5 \mathrm{~m}^{3}}{6 \mathrm{jam} \times 1 \mathrm{~m}^{3} / \mathrm{jam}}$

Tenaga Kerja $=14,58$ orang $\rightarrow$ dibulatkan 15 orang.

2. Perkiraan Tenaga Kerja Alat Pencacah
Beban Kerja $: 43,75 \mathrm{~m}^{3}$
Waktu yang diperkirakan $: 6 \mathrm{~m}^{3} / \mathrm{jam}$
Waktu operasi 1 alat : 4 jam

Perhitungan :

Tenaga Kerja $=\frac{\text { Beban Kerja }}{\text { Waktu untuk } 1 \text { org } \times \text { waktuo }}$

Tenaga Kerja $=\frac{43,75 \mathrm{~m}^{3}}{6 \mathrm{~m}^{3} / \text { jam } 4 \text { jam }}$

Tenaga Kerja=1,82 orang $\rightarrow$ dibulatkan 2 orang.

Tabel 8. Sistem Operasional Setelah Pengembangan

\begin{tabular}{|c|l|c|c|c|c|}
\hline No & Pekerjaan & Waktu & $\begin{array}{c}\text { Tenaga } \\
\text { Kerja } \\
\text { (orang) }\end{array}$ & Perlengkapan & $\begin{array}{c}\text { Jumlah } \\
\text { Sampah }\end{array}$ \\
\hline 1 & Pemilahan Sampah & $07.30-13.30$ & 15 & $\begin{array}{c}\text { Pemilahan Manual } \\
\text { Pencacah Organik }\end{array}$ & $87,5 \mathrm{~m}^{3}$ \\
\hline 2 & $\begin{array}{l}\text { Pencacahan } \\
\text { Sampah Organik }\end{array}$ & $13.30-15.30$ & 2 & $\begin{array}{c}\text { Alat Pencacah } \\
\text { Organik }\end{array}$ & $43,75 \mathrm{~m}^{3}$ \\
\hline
\end{tabular}


Tabel 9. Perkiraan Biaya Operasional Setelah Pengembangan

\begin{tabular}{|c|c|c|c|c|c|}
\hline NO & Uraian & $\begin{array}{c}\text { Biaya Satuan } \\
\text { (Rp) }\end{array}$ & Volume & $\begin{array}{l}\text { Biaya Total } \\
\text { (Rp) / hari }\end{array}$ & $\begin{array}{l}\text { Biaya per bulan } \\
\text { (Rp) }\end{array}$ \\
\hline 1 & Tenaga Kerja & 100.000 & 17 orang & 1.700 .000 & 51.000 .000 \\
\hline 2 & Pemeliharaan alat & & 3 alat & & 1.320 .000 \\
\hline \multicolumn{3}{|c|}{ Pengeluaran } & \multicolumn{2}{|r|}{ Jumlah } & 52.320 .000 \\
\hline 3 & \multicolumn{4}{|l|}{ Hasil Produksi } & 41.469 .750 \\
\hline 4 & \multicolumn{4}{|l|}{ Biaya Pengangkutan } & 17.326 .000 \\
\hline \multicolumn{3}{|c|}{ Pemasukan } & & Jumlah & 58.795 .750 \\
\hline
\end{tabular}

Tabel 10. Perbandingan Sebelum dan Sesudah Pengembangan

\begin{tabular}{|c|c|c|c|}
\hline No & Uraian & Sebelum Perencanaan & Sesudah Perencanaan \\
\hline \multicolumn{4}{|c|}{ I. Sistem Operasional Pengolahan Sampah } \\
\hline \multirow[t]{2}{*}{1} & Pengolahan Sampah & - Pemilahan Sampah & - Pemilahan Sampah \\
\hline & & $\begin{array}{l}\text { - Pencacahan Sampah } \\
\text { Organik } \\
\text { - Pengepakkan botol } \\
\text { plastik } \\
\text { - Residu }\end{array}$ & $\begin{array}{l}\text { - Pencacahan Sampah } \\
\text { Organik } \\
\text { - Pengolahan Sampah } \\
\text { dengan Biodigester } \\
\text { - Pengepakkan Sampah } \\
\text { Plastik botol dan kresek } \\
\text { - Residu }\end{array}$ \\
\hline 2 & Waktu & $08.00-12.00$ & $07.30-15.30$ \\
\hline 3 & Tenaga Kerja & 2 & 15 \\
\hline 4 & Hasil Sampah Diolah & $13,12 \mathrm{~m}^{3}$ & $77 \mathrm{~m}^{3}$ \\
\hline \multicolumn{4}{|c|}{ II. Biaya Operasional } \\
\hline 1 & Biaya Pemasukkan & Rp 8.505.000 & Rp 58.795.750 \\
\hline 2 & Biaya Pengeluaran & Rp 7.000.000 & Rp 52.320.000 \\
\hline \multicolumn{4}{|c|}{ III. Biaya Pengangkutan } \\
\hline 1 & Hasil Sampah untuk TPA & $74,37 \mathrm{~m}^{3}$ & $10,5 \mathrm{~m}^{3}$ \\
\hline 2 & Biaya Pengangkutan & Rp. 25.989.000 & Rp 8.663.000 \\
\hline
\end{tabular}

Metode Pay Back Period (PBP) merupakan suatu periode yang diperlukan untuk menutup kembali pengeluaran suatu investasi dengan menggunakan aliran kas masuk netto (proceeds) yang diperoleh. Perhitungan waktu pengembalian bersifat umum dan hanya untuk mengetahui gambaran dari waktu yang diperlukan untuk mengembalikan modal. berikut :

Perhitungan pay back period (PBP) sebagai

Perkiraan laba per bulan adalah Rp. 8.878.750,didapat dari

Laba per bulan = biaya pemasukkan - biaya pengeluaran

Laba per bulan $=$ Rp. 58.795.750,- $-\mathrm{Rp}$. 52.320.000,-

Laba per bulan $=$ Rp. 6.475.750,-

Jadi perhitungan untuk PBP adalah

pay back period $(\mathrm{PBP})=\frac{\text { biaya investasi }}{\mathrm{Laba}}$

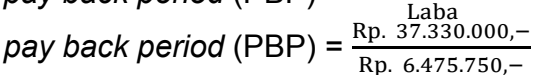

pay back period $(\mathrm{PBP})=5,76$ Bulan $\approx 6$ Bulan

Sehingga perkiraan waktu yang diperlukan untuk mengembalikan modal adalah 6 bulan.

Dengan alternatif biodigester tersebut diharapkan dapat mengurangi penumpukkan sampah yang diakibatkan oleh produksi sampah yang semakin meningkat dan mengurangi waktu tunggu untuk mengangkut sampah menuju ke TPA Rawa Kucing sehingga tidak ada wasting time dari penggunaan alat. Pengaplikasian biodigester juga menghasilkan pengolahan sampah yang lebih bermanfaat seperti listrik, pupuk dan gas metan yang dapat menghasilkan nilai ekonomis untuk pendapatan TPST. Selain itu dapat mengurangi pencemaran yang dihasilkan dari penumpukkan sampah. Sehingga tercipta upaya konservasi lingkungan sebagai salah satu langkah untuk mewujudkan kelestarian sumber daya alam dan meningkatkan kesejahteraan manusia.

\section{KESIMPULAN}

1. Perencanaan desain biodigester menurut fungsi area disesuaikan dengan volume sampah yang masuk ke TPST, dari analisa data didapatkan volume total tangki digester adalah 196,8 $\mathrm{m}^{3}$ yang digunakan untuk mengolah sampah $32,8 \mathrm{~m}^{3} /$ hari.

2. Berdasarkan hasil perencanaan didapatkan penurunan volume sampah yang dikirim ke TPA Rawa Kucing dari $87,5 \mathrm{~m}^{3} /$ hari masih ada $\pm 10,50 \mathrm{~m}^{3} /$ hari sampah. Hal ini menunjukkan bahwa teknologi biodigester dapat menjadi salah satu penyelesaian permasalahan sampah di TPST GEMPEL BEHI.

3. Pengolahan sampah organik dengan teknologi biodigester dapat memberikan manfaat bagi masyarakat diantaranya pendapatan dari nilai ekonomis sampah seperti pupuk, gas dan listrik, selain itu dapat mengurangi permasalahan sampah yang muncul di masyarakat, sehingga tercipta upaya konservasi lingkungan sebagai salah satu langkah untuk mewujudkan kelestarian sumber daya alam dan meningkatkan kesejahteraan manusia.

\section{DAFTAR PUSTAKA}

Amandasari, N., Ainun, S., \& Hartati, E. (2016). Studi Komparasi Sistem Pengelolaan Sampah dengan Biodigester Kelurahan Cibangkong dan Kelurahan Cilengkrang. Bandung : Jurusan Teknik Lingkungan, Fakultas Teknik Sipil dan Perencanaan, ITENAS

Artiani, Gita P., \& Handayasari, Indah. (2015). Konservasi Lingkungan Melalui Perencanaan Tempat Pengolahan Sampah Terpadu Berbasis Komunitas (Prosiding Semnastek FT UMJ). Jakarta: Universitas Muhammadiyah Jakarta.

Bandung, Juju. (2012). Usaha Konservasi

Lingkungan Hidup.

http:/jujubandung.wordpress.com/2012/10/18/ usaha-konservasi-lingkungan-hidup/ (25 April 2017).

Bappeda Kabupaten Grobogan. (2017). Kajian dan Penelitian Penerapan Teknologi Biogas Sebagai Sumber Energi Alternatif. https://bapeda.grobogan.go.id (5 Agustus 2017).

Ermawan, Hamidan Arief. (2016). Perencanaan Tempat Pengolahan Sampah Terpadu dengan Mengoptimalkan Alur Pengolahan Sampah sebagai Upaya Konservasi Lingkungan. Jakarta : Fakultas Teknik Sipil STT-PLN Jakarta. 
Permen PU No. 3 Tentang Penyelenggaraan Prasarana dan Sarana Persampahan dalam Penanganan Sampah Rumah Tangga dan Sejenis Sampah Rumah Tangga.

PT. Gas Depo Industry. (2016). Jual Gas Methane. http://gasdepo.co.id/jual-gas-methane Agustus 2017)

Rumah Energi. (2015). Peluang Bio-slurry Sebagai Penopang Ekonomi Masyarakat. http://www.biru.or.id/index.php/news/2016/11/1 1/246/ peluang-bio-slurry-sebagai-penopangekonomi-masyarakat.html (27 Juli 2017).

Safitri, Ervita. (2015). Analisis Keputusan Investasi (Capital Budgeting). https://simponi.mdp.ac.id/materi201120121 (14 Juni 2017).

Sistem Penanganan Sampah TPA Kabupaten Pati. Dinas Pekerjaan Umum Kabupaten Pati.

SNI 19-454-2002 Tentang Tata Cara Teknik Operasional Pengelolaan Sampah Perkotaan.

Suyitno, (2009), Pembangkit Listrik Tenaga Biogas (PLTBio) yang Dilengkapi dengan Kompresi Biogas, Balitbang Jateng, Indonesia.

Syabani, Muhammad Rizki. (2014). Anaerobic digester (Biodigester) dan Biogas. Bandung : Fakultas Teknik Institut Teknologi Bandung.

Undang Undang Republik Indonesia No 18 Tahun 2008 Tentang Pengelolaan Sampah. Departemen PU. Jakarta.

Waskito, Didit. (2011). Analisis Pembangkit Listrik Tenaga Biogas dengan Pemanfaatan Kotoran Sapi di Kawasan Usaha Peternak Sapi. Depok : Fakultas Teknik Universitas Indonesia.

Wikipedia Sampah. https://id.wikipedia.org/wiki/ Sampah (2 April 2017).

www.engr.usask.ca/classes/ABE/482/notes/ABELec ture09

Yogiesti, V., Hariyani, S., \& Sutikno, F.R. (2010). Pengelolaan Sampah Terpadu Berbasis Masyarakat Kota Kediri. Malang : Jurusan Perencanaan Wilayah dan Kota Fakultas Teknik Universitas Brawijaya

Zachrayni, I. 2009. Pembuatan Biogas Dari Limbah Peternakan (Jurnal). Fakultas. Peternakan Undip, Press : Semarang. Dalam, Herlina, Dewi, M., dkk,. 2010. 